\title{
The Impact of Atmospheric Factors on Repurchase Intention at Upscale Restaurants in Ho Chi Minh City, Vietnam
}

\author{
Mai Ngoc Khuong and Dao Ngoc Quynh
}

\begin{abstract}
This study aimed to explore the atmospheric factors that impact customer repurchase intention at upscale restaurant, thus, provide learning and recommendations for restaurant owners in Ho Chi Minh City to adjust marketing strategy. In relevant to Ho Chi Minh context, this study conducted the research of 6 main factors including: Sight, Scent, Touch, Menu, Music and Social Factors with totally 15 sub-factors with 82 items. Based on the result of Regression Analysis, there were 5 remaining variables influencing Repurchase Intention at upscale restaurant namely 1) External Facility from Sight, 2) Congruent Scent from Scent, 3) Menu, 4) Music background from Music and 5) Employee Attitude from Social Factors. These accounts for $59.7 \%$ of Repurchase Intention.
\end{abstract}

Index Terms-Atmospheric environments, repurchase intention, upscale restaurant.

\section{INTRODUCTION}

\section{A. Background}

In recent years, Vietnam's economy has been recovering and growing at high speed thanks to open strategy that attracts foreign investors. Particularly, this creates chances for food service sector to grow and diversify with cultural cuisine, especially in metropolitan city such as Ho Chi Minh City with large population of over 8 million, thanks to the growing popularity of eating out, especially among the young generation, and the great efforts made by food service operators. Based on [1], nationwide food service sales reached an estimated record $\$ 36.2$ billion in 2013. There were in five major sub-sectors foods-services in Vietnam: 1) Street Stalls/Kiosks, 2) Cafeteria/bars, 3) Full-Service Restaurants, 4) Quick Service Restaurants or Fast Food Chains, and 5) Catering Service Companies.

\section{B. Problem Statement}

Traditional street stalls/kiosks and full-service restaurants in Vietnam are those that embraced up to $94 \%$ approximately out of 558,000 outlets, definitely dominated in sales. They covered a crowded density and offered consumers a diversified product portfolio in taste and cuisine from Western to Asian dishes. Recently, in urban cities namely Ho Chi Minh, full-service restaurants have been firmed to a new service under chained stores that serve higher income

Manuscript received October 16, 2017; revised February 7, 2018.

Mai Ngoc Khuong (PhD.) and Dao Ngoc Quynh are with the School of Business Administration, VNU-HCM International University, Vietnam (e-mail: mnkhuong@hcmiu.edu.vn, cheesiedaongocquynh@gmail.com). consumers and/or foreign tourists, such as Gogi (Korean-themed), Tokyo Deli (Japanese) and MK (Thai). They bring a new flavor of food together with high-investment on place ambience, attentive customer services and ramp up along with spacious supermarkets/shopping mall; this [2] satisfies customer's expectation, eventually, rose up return intention.

\section{LITERATURE REVIEW}

\section{A. Upscale Restaurant}

Within full-service, it divides into hierarchy of professionalism from casual dining to luxury one. According to [3], upscale dining restaurants are defined as a full-service restaurant with better menu serving diverse choices of food and beverage. Besides that, the restaurant appearance also looks more sophisticated with clever decoration and ambiance, well-trained waiters wearing the same uniform, all together enhance customer's experience while enjoying in restaurants. Similarly, place ambience attains better attention comparing to product in the making purchase decision. As a result, ambience design and organization play a competitive strategy in modern restaurants business nowadays.

\section{B. Repurchase Intention}

Repurchase intention is a degree to which customers are willing to buy a product again and has also been operated as the probability that a consumer will buy a product or service more time [4]. Customers' repurchase intention depends on the value obtained in their previous transactions [5]. Significant, as reported by [6], for business investment, focusing on Repurchase Intention is a right strategy as it is less costly comparing to the marketing cost for collecting new customer. Importantly, the correlation between atmospheric factors and repurchase intention is supposed to be quite close in restaurant business. Some elements namely, music, location, space and social factors directly affect customer experience thus indirectly influence repurchase intention to those who had been to shop.

\section{Atmospheric Factors}

As stated in [7], restaurant environment is the physical surroundings established and controlled by the owners. Particularly in restaurant business, besides food taste, any surrounding activities from decoration, sounds to social factors can indirectly or directly affect the satisfaction while enjoying the meal at restaurant [8].

According to [9], in-store atmosphere reinforces purchase 
possibility by creating emotional effects via single elements containing in atmosphere in store such as sight, sound, scent and touch.

Similarly to [10], "general interior" atmospherics category includes music, sound, lighting, scent, color, temperature (often referred to as "ambient" environmental cues), and visual design elements.

In addition, DINESCAPE scale in restaurant area [11] introduced new term that was well adapted to upscale restaurant including: facility aesthetics, lighting, ambience, layout, table settings, and service staff. Besides that [12], space, design, color, and music are also indeed elements for full-service restaurant.

In addition, non-environmental store criteria induce customers' emotions, thus influencing behavioral intentions [12]. In the restaurant context, non-environmental criteria typically involve four elements: food quality, service quality, price, and location [13]. Based on the above discussion, it can be theorized that both environmental cues and non-environmental cues positively influence patrons' emotional responses.

In combination of these theories and consideration for Vietnamese restaurant context, this study aims to explore the relation of atmospheric and non-atmospheric factors on repurchase intention such as: 1) Sight, 2) Scent, 3) Sound, 4) Touch, 4) Social factors, and 5) Menu

\section{1) Sight}

\section{a) External facility}

The first thing that grasps the consumers' attention while approaching an upscale restaurant is the exterior facility. Exterior attributes have been sparingly dealt with in scientific researches such as [14] examined the influence of exterior display windows, [15] examined the influence of parking lots and location, in which location plays an important role in decision-making process. In a common sense, most patrons would prefer a convenient place, which takes less travel effort [16].

\section{b) Internal layout}

This is about interior decoration and concept that restaurant owners build as distinguished points to others. In term of concept, [17] indicated that "color, brightness, size, and shapes can impact consumers' purchase intention”, especially light colors, which associate with pleasure and arousal [18] that draw consumer's attention. More specifically, as stated by [8] tangible cues are essential components to accelerate the attractiveness of the physical environment including "the color schemes of the dining area, ceiling/wall decorations, pictures/paintings, plants/flowers, tableware (e.g. glass and silverware), linens (e.g. table cloths and napkin), floor coverings, and quality furniture (e.g. dining table and chair)".

c) Restaurant layout

Spatial layout refers to the arrangement of objects such as machinery, equipment, and furnishings, the size and shape of the objects, and the spatial relationships among those objects (tables, seats, aisles, food service lines, restrooms, etc.) [19]. The effectively designed spatial layout of a physical environment is important in achieving customer satisfaction because it fulfills functional needs and gives a sense of comfort to customers, thus results in a positive emotional responses to restaurant service [20].

2) Scent

Scent is the one that spread into the environments with or without customer awareness about it, this makes customer feel hungry and feel the taste of the food long before they pass the store. According to [21] scents has high effect on overall mood, purchase and re-purchase intention by $43 \%$ positively. Scent can be classified into three main aspects for detail investigation: freshness, congruent scent, and tobacco smoke.

a) Fresh scent

This is what in the air can change customer mood state and affects elaboration; also, [22] found that pleasant odors create pleasant mood states.

\section{b) Congruent Scent}

In the context of upscale restaurant, this can includes aroma ambience and food scent that appeal customers. In addition, [23] shows that pleasant scent and consent scent elaborated the increase of spending money and time in the retail context, which proved by the fact that food smell in bakery shop helped increase the sale as much as $300 \%$ [24].

\section{c) Tobacco smoke}

In the research model of [10], tobacco smoke variable is studied because it is both relevant and deserving of future atmospheric study. It is proven to have a link between the tobaccos and marketing, tobacco smell usually annoys customers in nearby atmosphere.

\section{3) Music}

Music has long been an efficient and effective ways to trigger mood and verbal communication. In consumer marketing, music is a major element at the point of purchase, as well as in advertising [25]. The music playing on the background influences consumer's emotional feeling, service or product judgment, and consumer decision, as a part of atmosphere and a part of ambience [8]. As reported by [26], slow music playing in the restaurant took more time for customers to finish their meals and leave than fast music, thus influence dining experience and revisit intention.

\section{4) Мепи}

As written in [27], it is said, "A restaurant menu is more than just a list of food with prices. It is a reflection of your restaurant style and concept. A restaurant menu is not something to be hastily written up, but rather an important marketing tool that should be carefully considered". There are three main parts of designing a restaurant menu: Description, Layout and Pricing.

\section{5) Touch}

According to [9] touch is classified into three dimensions: temperature, softness, and smoothness. In restaurant context, they usually perceive the touch environments around such as color, texture, and pattern of the materials called surface materials through the use of wood, fabric, leather, and other materials to seek for the smoothness, toughness, softness, otherwise, sitting on hard surface would lead patrons leave soon [28]. Besides that, temperature is quite significant as physically uncomfortable if customers sweat, they might never return [29]. 


\section{6) Social Factors}

Social factors refer to the people (i.e., employees and their customers) in the service setting. Criteria belongs to social variables are employee appearance, Employee behaviors, dress or physical appearance of other customers.

According to [30], interaction between customers and staff includes service employees' responsiveness, assurance, and empathy while providing services. Besides that, staff uniform plays a crucial role in creating positive impression about restaurant, showing that this is professional one, which is moderately important to upscale restaurant. Clothes must be moderate, appropriate and send positive messages.

A professional employee uniform may effectively convey an organization's image and core values in a very up-close-and-personal way. [31] Further claimed that service staff are related to the desired social density, which affects customer affective and cognitive responses as well as repurchase intentions. Similarly, [11] supported the strong influence of employees on customers' pleasure and arousal states.

\section{METHODOLOGY}

\section{A. Research Design}

Quantitative method is the main approach applied for this study. This type of research is measurable which quantify in number so that the data collected can be comparable and useful results. In addition, to meet the hard requirement in term of reliability of responses, quantitative method can be tested via SPSS tool. As a result, the result of research that was given could be more scientific and objective which supports for precise decision making.

\section{B. Research Sample}

This study conducted in Ho Chi Minh city, Vietnam - a metropolitan center, which leads in food culture and high standard of living. The sample size of 330 respondents meets condition of Factor Analysis. Importantly, respondents are highly restricted to those who exposed to upscale restaurant services.

\section{Research Instrument and Data Collection}

Stated by [32], "Observation, interview and questionnaire are considered the three well-known methods of data collection". As presented in Research Design, survey is the applicable method that ensures the objective of final; besides that, it is efficiently to do in a mass sample size of 300 interviewees. Hence, questionnaire was chosen and designed to gather desired information for this research. In order to ensure answer quality, face-to-face interview is used to approach respondents.

\section{1) Research instrument}

Independent and Dependent variables questions applied 5-point Likert scale in which: 1 - Strongly disagree; 2 Disagree; 3 - Neutral; 4 - Agree; 5 - Strongly agree. Besides that, nominal scale is applied for Gender and Frequency visit for simple variable. In addition, ratio scale applied for Age, Occupation, Income, and Spend to determine the clear range among items.

\section{2) Data ANALYSIS}

This study applied mainly three methods to analyze including: Exploratory Factor Analysis (EFA), Reliability Analysis and Regression Analysis.

3) Factor analysis (EFA) and reliability test (Exploratory factor analysis EFA)

Factor analysis in SPSS is known as data reduction technique to eliminate invalid items out of the large set [33]. In addition, Reliability Test is a technique of SPSS used to test the consistency of measurement scale, using Cronbach's alpha as an indicator of which value varies from 0 to 1 , the higher degree, the better [34]

After running for 38 rounds with different perspectives, all data set independent and dependent variables were proper to conduct factor analysis, as below:

TABLE I: SUMMARY OF THE DEPENDENT VARIABLES WITH RELIABILITY COEFFICIENT

\begin{tabular}{lcc}
\hline \hline \multicolumn{1}{c}{ Dependent Variable Names } & $\begin{array}{c}\text { Number of } \\
\text { items }\end{array}$ & $\begin{array}{c}\text { Cronbach's } \\
\text { alpha }\end{array}$ \\
\hline 1. Repurchase Intention (REPURINT) & $7 *$ & .853 \\
\hline Cronbach alpha values $>.6$ & \\
$*$ All items have factor loadings $\geq .5$ & \\
KMO index $=.844$ and Sig. of Bartlett's test $=.000<.05$ & \\
Total variance explained $=53.442 \% \geq 50 \%$ \\
Eigenvalues values $>1$
\end{tabular}

According to Table I, dependent variables was appropriate to conduct factor analysis with KMO index $>.5$ and Bartlett's test sig $<.05$. Besides that the amount of variance in all tests was acceptable with Eigenvalues values $>1$ and Total variance explained $=53.442 \% \geq 50 \%$. Also, All items had factor loadings $\geq .5$ proves that "The correlation between each variable and the factor was acceptable." Besides that, Cronbach's alpha values of .853 stated a good reliability in consistency of measurement scale.

TABLE II: SUMMARY OF THE INDEPENDENT VARIABLES WITH RELIABILITY COEFFICIENT

\begin{tabular}{lcc}
\hline \hline Independent Variable Names & $\begin{array}{c}\text { Number of } \\
\text { items }\end{array}$ & $\begin{array}{c}\text { Cronbach's } \\
\text { alpha }\end{array}$ \\
\hline 1.Smoothness (SMOO) & $6^{*}$ & .859 \\
2.External Facility (EXFA) & $6^{*}$ & .827 \\
3.Attitude (ATTI) & $4^{*}$ & .890 \\
4.Music Background (MUBA) & $4^{*}$ & .811 \\
5.Tobacco Smoke (TOSMO) & $3^{*}$ & .756 \\
6.Menu (MENU) & $3^{*}$ & .825 \\
7.Congruent Scene (COOD) & $3^{*}$ & .817 \\
8.Temperature (TEMP) & $3^{*}$ & .705 \\
9.Music Volume (MUVO) & $3^{*}$ & .731 \\
\hline Cronbach alpha values > .6 & \\
*All items have factor loadings $\geq .5$ & \\
KMO index = .812 and Sig. of Bartlett's test $=.000<.05$ \\
Total variance explained = 7.487\% $\geq 50 \%$ \\
Eigenvalues values > 1 \\
\hline \hline
\end{tabular}

As shown in Table II, the KMO index was .812> .5 and Bartlett's significant $p<.05$, explaining, "The data set was appropriate for conducting factor analysis." Also, Eigenvalues values $>1$ and total variance explained was $7.487 \%>50 \%$ of standard, these meant "The amount of variance in all the tests that had been accounted for by the factor were acceptable". In addition, all loading factors were > .5 which vary from .705 to .890 means "The 
correlation between each variable and the factor was acceptable." Finally, yet importantly, Cronbach's alpha values were good with minimum value of .705 and maximum on of .890 showing that measurement scale was consistent.

After the data processing, this study hypothesized that:

H: Smoothness, External Facilities, Interior Layout, Restaurant Layout, Freshness, Employee Attitude, Music, Tobacco Smoke, Menu, Congruent Scent, Temperature, Softness, Availability, Response and Uniform significantly affect Repurchase Intention

\section{RESEARCH FINDINGS}

\section{A. Descriptive Analysis}

TABLE III: DEMOGRAPHIC

\begin{tabular}{lll}
\hline & \multicolumn{2}{l}{ TABLE III: DEMOGRAPHIC } \\
\hline Items & Percentage \\
\hline Age & Male & $43 \%$ \\
& Female & $57 \%$ \\
\hline & Under 18 & $1 \%$ \\
& $18-25$ & $37 \%$ \\
& $26-30$ & $35 \%$ \\
& Above 45 & $21 \%$ \\
\hline Occupation & Student & $6 \%$ \\
\hline & Office staff & $13 \%$ \\
& Free lancer & $67 \%$ \\
& Civil servant & $19 \%$ \\
& Others & $1 \%$ \\
\hline Spend per meal & Under \$5/pax/person & $19 \%$ \\
& \$5 - \$10/pax/person & $21 \%$ \\
& \$10 - \$15/pax/person & $23 \%$ \\
& \$15 - \$25/pax/person & $27 \%$ \\
& Above \$25/pax/person & $10 \%$ \\
\hline Income & Under \$200/month & $5 \%$ \\
& \$200 - \$450/month & $10 \%$ \\
& \$450 - \$700/month & $20 \%$ \\
& \$700 - \$1000/month & $23 \%$ \\
& Above \$1000/month & $42 \%$ \\
\hline \hline
\end{tabular}

Based on Table III, it showed that sample size varied equally between Male and Female (approximately 50\% each). Most of respondents belonged to 18-35 age group (71\%). Besides that, officers took high proportion of respondents (67\%). In addition of spend, $50 \%$ respondents paid from $\$ 10$ to $\$ 25 / \mathrm{pax} / \mathrm{meal}$. Moreover, $43 \%$ of them earned on average of $\$ 450$ to $\$ 1000$ monthly.

TABLE IV: CORRELATIONS BETWEEN VARIABLES

\begin{tabular}{lccccccccc}
\hline \multicolumn{1}{c}{ REPU } & RINT & 1 & 2 & 3 & 4 & 5 & 6 & 7 & 8 \\
\hline 1. SMO & -.110 & 1.00 & & & & & & & \\
2. EXFA & .581 & -.088 & 1.00 & & & & & & \\
3. ATTI & .534 & .071 & .404 & 1.00 & & & & & \\
4. MUBA & .453 & -.230 & .340 & .322 & 1.00 & & & & \\
5. TOSMO & -.127 & .194 & -.069 & -.011 & -.239 & 1.00 & & & \\
6. MENU & .581 & -.190 & .457 & .477 & .387 & -.179 & 1.00 & & \\
7. COSCE & .576 & -.133 & .456 & .334 & .297 & .067 & .389 & 1.00 & \\
8. TEMP & .149 & -.266 & .147 & .000 & .206 & -.049 & .255 & .253 & 1.00 \\
9. MUVO & .153 & -.001 & .113 & .043 & .203 & .062 & .106 & .165 & .232 \\
\hline \multicolumn{1}{c}{ Mean } & 4.01 & 3.28 & 4.05 & 4.22 & 3.31 & 4.53 & 4.06 & 4.04 & 2.86 \\
\hline \multicolumn{1}{c}{ SD. } & .560 & .481 & .663 & .754 & .741 & .606 & .715 & .725 & .466 \\
\hline
\end{tabular}

As shown from Table IV, in general, there were 7 variables that have positive correlations and 2 variables that had negative correlations to Repurchase Intention. Specifically, External Facility (EXFA) $(r=.581, \quad p=.000)$, Employee Attitude (ATTI) ( $r=.534, p=.000)$, Menu (MENU) $(r=.581$, $p=.000)$, Congruent Scent (COSCE) $(r=.576, p=.000)$, Music Background (MUBA) $(r=.453, p=.000)$ had moderately positive correlations with Repurchase Intention (REPURINT). Besides that, Temperature (TEMP) $(r=.149$, $p=.000)$ and Music Volume (MUVO) $(r=.153, p=.000)$ had low positive correlation to Repurchase Intention (REPURINT).

By contrast, Smoothness (SMO) $(r=-.110, p=.000)$ and Tobacco Smoke (TOSMO) $(r=-.127, p=.000)$ had negative correlation to Repurchase Intention (REPURINT).

\section{B. Factors Affect on Repurchase Intention}

TABLE V: SUMMARY OF THE INDEPENDENT VARIABLES WITH RELIABILITY

\begin{tabular}{|c|c|c|c|}
\hline Variables & $\begin{array}{c}\text { Standardized } \\
\text { Coefficients }\end{array}$ & $t$ & Sig. \\
\hline SMO & .006 & .132 & .895 \\
\hline EXFA & .222 & 4.452 & .000 \\
\hline ATTI & .196 & 3.905 & .000 \\
\hline MUBA & .130 & 2.685 & .008 \\
\hline TOSMO & -.065 & -1.499 & .135 \\
\hline MENU & .219 & 4.146 & .000 \\
\hline COSCE & .298 & 6.079 & .000 \\
\hline TEMP & -.052 & -1.149 & .252 \\
\hline MUVO & .037 & .868 & .386 \\
\hline \multicolumn{4}{|c|}{$\begin{array}{l}* \text {. Coefficient is significant at the } .05 \\
\text { Dependent Variable: REPURINT } \\
\text { ANOVA: } \mathrm{F}=4.301, \text { Sig. }=.000 \\
\text { Model summary: Adjusted R2 }=.597\end{array}$} \\
\hline
\end{tabular}

Similarly, as shown from Table V, with Sig $\leq .05$, there were External Facility (EXFA) (Sig.= .00 $\leq .05)$, Employee Attitude (ATTI) (Sig.= .000 $\leq .05) ;$ Music Background $($ MUBA) $($ Sig. $=.008 \leq .05)$; Menu (MENU) $($ Sig. $=.000 \leq .05)$; Congruent Scent (COSCE) (Sig. $=.000 \leq .05)$ that had unique contribution to Repurchase Intention (REPURINT). On the other hand, Smoothness (SMO) (Sig.=.579 $\geq .05)$, Temperature (TEMP) (Sig. $=.677 \geq .05)$ and Music Volume (MUVO) (Sig.= .492 $\geq .05)$ and Tobacco smoke (TOSMO) (Sig.=.135 $\geq .05$ ) did not have contribution to Repurchase Intention.

Importantly, based on the Table $\mathrm{V}$, the R-square value was . $597(59.7 \%$ ) which explained that the total 5 components of Independent variables accounting for $59.7 \%$ of atmospheric factors that closely affected Repurchase Intention. These 5 components included: External facilities, Employee Attitude, Menu, Music background, Congruent Scent. In line with this, the other $41.3 \%$ unexplained was belonging to other factors unmentioned.

\section{DISCUSSION AND RECOMMENDATION}

\section{A. Independent and Dependent Variables}

According to the research finding which showed that ambience factors contributed $59.7 \%$ on Repurchase Intention, therefore, upscale restaurant owners should focus on enhancing individual items such as External Facilities, 
Employee Attitude, Menu, Music Background, Congruent Scent to improve restaurant ambience.

Starting with Congruence Scent (COSCE), this strongly affected REPUINT with the largest value of $\beta=.298$. As stated by [21] customer revisit intention to store and purchase goods were positively influenced by scent in $43 \%$. Therefore, Scent is applicable at $\mathrm{Ho} \mathrm{Chi}$ Minh restaurants by finding well-matching scent to store style and brand image, also store-keepers should manipulate smell in an adequate amount [35] thus overall remain patrons to stay longer at restaurants and augment customer experience.

Secondly, Menu (MENU) also affected REPUINT with proven $\beta=.219$. Menu plays as a "reflection of restaurant style and concept" where interacts with customers mostly and captures all about restaurant characteristics, food diversity, prices, etc. Menu can be improved by demonstrating clearly Best-Seller items as restaurant specialties recommended to new customers to save patrons time. In addition, designing menu that matches restaurant style is a good way to make consistency and impress customers. Moreover, customer care at upscale restaurant can satisfy difficult customers through how detail they describe dish ingredients so that patrons can be aware of allergic foods; lastly, it is important to refresh menu and update with discount programs to attract customers for next purchase.

Next, to an extent of External facility, firstly, it is best to equip a parking lot with clear accessible guide for customers [36], especially; this is a sensitive concern to travelers in Ho Chi Minh City who mainly use motorbikes. Besides that, restaurant sign should be eye-catching to get attention from far distance and entrance should be wide and has step-free to avoid fall [37]. Significantly, in digital world, upscale restaurant should create their own website to accelerate online access and awareness to customers.

Besides that, Employee Attitude plays an important role to Repurchase Intention. [37] Showed that revisit intention may drop up to $47 \%$ once staff is under performed. As a result, staff training section is required to enhance manners, skills and service assistance to patrons. An efficient way to encourage staff performance is to give frequent reward and recognition. In addition, restaurants manager should be able to give advices and feedbacks in deed.

Another factor helps to lighten up ambience is Music Background that has been popularly applied as a strategic way to enhance store atmosphere. According to a research conducted in Dallas and Texas at upscale restaurant, slow-tempo music background is recommended to encourage patrons staying longer at store. In addition, it is literally to play right music at right period of day, for instance, at high traffic hours such as lunch and nighttime, fast-tempo music is best applied to increase table over. By contrast, slow-tempo music is applied at empty time, as there is enough space for patrons to enjoy. In addition, choose appropriate music type that matches store style is important to define brand positioning, for instance, a restaurant with tropical theme matches well with Caribbean instrumental music.

\section{B. Limitations and Recommendations for Future Researches}

First is niche research area. Mainly, this research was conducted in Ho Chi Minh City to evaluate the response of local residents only. Therefore, for oversea businessman, this study was not able to provide a full view of Vietnamese Nationwide. For a better learning, the similar topic should be conducted in Ha Noi, Da Nang, and Can Tho - the 4 key cities of Vietnam representing culture in different regions namely North, Middle and South respectively.

Secondly, bias sampling method. The research was conducted with Random sampling method by which the sample may not well represent for the total Ho Chi Minh citizen differs from place of living, knowledge, and income.

Lastly, there was unfair ration among participant characteristic factors. Based on Descriptive analysis result, the ratio among age, income, occupation are not equally divided, therefore, it might affect the result once the number of one characteristic factor dominated over others.

\section{REFERENCES}

[1] G. Smith and V. Kiet. (August 2015). Food Service - Hotel Restaurant Institutional. GAIN Report Number: VM5053. p. 3. [Online]. Available: https://gain.fas.usda.gov/Pages/Default.aspx

[2] K. L. Wakefield and J. G. Blodgett, "The effects of the servicescape on customers' behavioral intentions in leisure service settings," Journal of Services Marketing, vol. 10, no. 6, pp. 45-61, 1996.

[3] K. M. Richard, "The 2011 restaurant, food \& beverage market research handbook," Loganville, GA: Richard K. Miller \& Associates, 2011

[4] M. N. Khuong and B. T. N. Giau, "The direct and indirect effects of advertising and public relation on repurchase intention through brand awareness and consumers' perception - A Case study of vinamilk, vietnam," presented at 4th International Conference on Business and Economic Research (4th ICBER-2013), Bandung, Indonesia, March 2013.

[5] E. B. Badr, B. I. Siddig, and H. A. Abdel, "The impact of relationship quality on repurchase intention towards the customers of automotive companies in Sudan," Journal of European and American, 2015.

[6] L. J. Rosenberg and J. A. Czepiel, "A marketing approach for customer retention," Journal of Consumer Marketing, 1984.

[7] W. G. Kim and Y. J. Moon, "Customers' cognitive, emotional, and actionable response to the servicescape: A test of the moderating effect of the restaurant type," International Journal of Hospitality Management, 28, pp. 144-156, 2009

[8] K. Ryu and S. Jang, "DINESCAPE: A scale for customers' perception of dining environments," Journal of Foodservice Business Research, vol. 11, no. 1, pp. 2-22, 2008.

[9] P. Kotler, "Atmospherics as a marketing tool," Journal of Retailing, vol. 49 , no. 4 , pp. 48-64, 1973.

[10] L. W. Turley and R. E. Milliman, "Atmospheric effects on shopping behavior: a review of the experimental evidence," Journal of Business Research, vol. 49, no. 2, pp. 193-211, New York: HarperCollins, 2000

[11] H. S. Han and K. Ryu, "The roles of the physical environment, price perception, and customer satisfaction in determining customer loyalty in the family restaurant industry," Journal of Hospitality \& Tourism Research, vol. 33, no. 4, pp. 487-510, 2009.

[12] S. Jang and Y. Namkung, "Perceived quality, emotions, and behaviora intentions: Application of an extended Mehrabian-Russell model to restaurants," Journal of Business Research, vol. 62, pp. 451-460, 2009.

[13] S. S. Hyun, "Predictors of relationship quality and loyalty in the chain restaurant industry," Cornell Hotel and Restaurant Administration Quarterly, vol. 51, no. 2, pp. 251-267, 2010.

[14] S. Edwards and M. Shackley, "Measuring the effectiveness of retail window display as an element of the marketing mix," International Journal of Advertising, vol. 11, no. 3, pp. 193-202, 1992.

[15] G. H. Tzeng, M. H. Teng, J. J. Chen, and S. Opricovic, "Multicriteria selection for a restaurant location in Taipei," International Journal of Hospitality Management, vol. 21, no. 2, pp. 171-87, 2002.

[16] A. Yüksel and F. Yüksel, "Measurement of tourist satisfaction with restaurant services: A segment-based approach," Journal of Vacation Marketing, vol. 9, no. 1, pp. 52-68, 2003.

[17] J. A. Bellizzi and R. E. Hite, "Environmental color, consumer feelings, and purchase likelihood," Psychology \& Marketing, vol. 9, no. 5, pp. 347-363, 1992. 
[18] A. Mehrabian and J. A. Russell, "An approach to environmental psychology,” Cambridge, MA, MIT Press, 1974.

[19] N. Nguyen and G. Leblanc, "Contact personnel, physical environment and perceived corporate image of intangible services by new clients," International Journal of Service Industry Management, vol. 13, pp. 242-262, 2002.

[20] I. Y. Lin, "Evaluating a servicescape: The effect of cognition and emotion," International Journal of Hospitality Management, vol. 23, no. 2, pp. 163-178, 2004.

[21] P. S. Ellen and P. F. Bone, "Does it amtter if it smells? Olfactory stimuli as advertising executional cues," Journal of Advertising, vol. 27, no. 4, pp. 29-39, 1998.

[22] H. Ehrlichman and L. Bastone, "Olfaction and emotion," in Science of Olfaction, M. J. Serby and K. L. Chobor, Eds. New York: Springer-Verlag, 1992, pp. 410-438.

[23] A. S. Matilla and J. Wirtz, "Congruency of scent and music as a driver of in-store evaluations and behavior," Journal of Retailing, vol. 77, no. 2, pp. 273-289, 2001.

[24] A. R. Hirsch, "Olfactory and psychiatry", paper presented at the 144th Annual Meeting, American Psychiatric Association, New Orleans, LA, 1991.

[25] C. Lovelock and J. Wirtz, "Services Marketing: People, Technology, Strategy," 6th Ed. Pearson Prentice Hall, New Jersey, 2007.

[26] R. E. Milliman, "The Influence of Background Music on the Behavior of Restaurant Patrons," Journal of Consumer Research, vol. 13, pp 286-9, September 1986.

[27] The balance. (2017). Tips for writing your restaurant menu - restaurant menu pricing, design and description. [Online]. Available: https://www.thebalance.com/tips-for-writing-your-restaurant-menu-2 888584

[28] M. J. Bitner, "Servicescapes: The impact of physical surroundings on customers and employees," Journal of Marketing, vol. 56, no. 2, pp. $57-71,1992$.

[29] W. Griffitt, "Environmental effects on interpersonal affective behavior: Ambient effective temperature and attraction," Journal of Personality and Social Psychology, vol. 15, pp. 240-244, 1970.

[30] M. K. Brady and C. J. Robertson, "Searching for a consensus on the antecedent role of service quality and satisfaction: An exploratory cross-national study," Journal of Business Research, vol. 51, pp. 53-60, 2001.
[31] A. Tombs and J. R. McColl-Kennedy, "Social-servicescape conceptual model," Marketing Theory, vol. 3, pp. 447-475, 2003.

[32] C. Bless and Q. H. Smith, "Fundamentals of Social Research Methods," An African Perspective, Cape Town, Creda Press, 1995.

[33] B. R. Williams, T. Brown and A. Onsman, Exploratory Factor Analysis: A Five-Step Guide for Novices, 3rd ed. Australia: Australasian Journal of Paramedicine, 2012.

[34] D. George and P. Mallery, SPSS for Windows Step by Step: A Simple Guide and Reference, 4th Ed, 11.0 update, Boston: Allyn \& Bacon, 2003.

[35] A. D. W. Rene, A. P. Ilse, B. Wilbert, C. Saskia and H. F. B. Johannes, "Food aroma affects bite size," BioMed Central, Flavor. 1:3, 2012.

[36] M. B. Pinto and L. Leonidas, "The Impact of Office Characteristics on Satisfaction with Medical Care: A Before and After Study," Health Marketing Quarterly, vol. 12, no. 2, pp. 43-54, 1994.

[37] W. Chan and Brenda, "Accessible cafés, restaurants and hospitality," Equality Commission for Northern Ireland Equality House, p. 21, 2014.

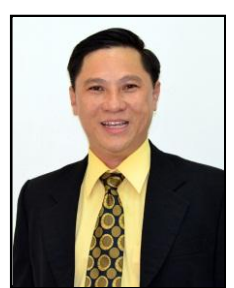

Mai Ngoc Khuong is a lecturer and researcher of School of Business Administration, International University, Vietnam National University - Ho Chi Minh. He has a bachelor degree in tourism and hospitality management, master of science degree in leisure, tourism and environment at Wageningen University - The Netherlands, and $\mathrm{PhD}$ degree in Development management at School of Public Administration of the National Institute of Development Administration (NIDA), Bangkok - Thailand.

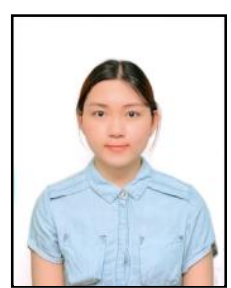

Dao Ngoc Quynh is a student of School of Business Administration, International University, Vietnam National University - Ho Chi Minh, who has completed her bachelor degree of business administration. She is specialized in marketing and interested in organizational behaviors, employee behaviors, leadership, operational management and entrepreneurship. 